\title{
Introduction to the Special Issue on the Economics of Climate Change Impacts on Developing Countries: Selected Studies on Sub-Saharan Africa and South-East Asia
}

\author{
Wisdom Akpalu ${ }^{1, *}$, Channing Arndt ${ }^{2, *}$ and Innocent Matshe $^{3}$
}

1 World Institute for Development Economics Research, United Nations University, C/O Institute of Statistical, Social and Economic Research, University of Ghana, P.O. Box LG 74 Legon, Accra, Ghana

2 World Institute for Development Economics Research, United Nations University, Katajanokanlaituri 6 B, FI-00160 Helsinki, Finland

3 African Economic Research Consortium, 3rd Floor, Mebank Building, Milimani Road, P.O. Box 62882-00200 Nairobi, Kenya; E-Mail: Innocent.Matshe@aercafrica.org

* Authors to whom correspondence should be addressed; E-Mails: akpalu@wider.unu.edu (W.A.); channing@wider.unu.edu (C.A.); Tel.: +233-20-961-2485 (W.A.); +358-09-615-9911 (C.A.); Fax: +358-09-615-99333 (C.A.).

Academic Editor: Marc A. Rosen

Received: 18 August 2015 / Accepted: 21 August 2015 / Published: 1 September 2015

Within the last century, the global average temperature increased by about $1{ }^{\circ} \mathrm{C}$ and this rate of increase may accelerate over the course of the 21 st century [1]. Although estimates of climate change are based on projections and probabilistic assessments, ample evidence exists that climate change impacts are likely to become more profound in this century, particularly if mitigation policies are absent or inadequate $[1,2]$. It has been argued that, relative to keeping the warming at $2{ }^{\circ} \mathrm{C}$ or lower, the global cost of continuing with "business as usual" may be 5 to 20 times higher $[3,4]$.

Changes in temperature and precipitation, and its impact, vary from region to region. Developing countries are likely to suffer relatively more from the impacts of climate change since they already have a disproportionate number of poor and marginalized people whose activities are frequently concentrated in climate sensitive sectors [5]. Also, developing countries have the least adaptive capacity to cope with a changing climate. Significant questions therefore exist with respect to the nature, scale, and timing of appropriate policy responses. Due to wide variations in climatic conditions across regions and countries in the developing world, detailed impact studies require assessments at local levels.

The objective of this Special Issue is to assemble studies of climate impacts and adaptations in countries in sub-Sahara Africa (Ghana (four studies); Ethiopia (two studies), Cameroon (one study)); 
and Southeast Asia (Vietnam (four studies)). The papers examine road infrastructure, hydropower generation, crop yields, adaptation among rangeland pastoralists, fish stocks, forestry and fuel interactions, and land rental decisions among smallholder female farmers. For Ghana and Vietnam, sectoral impacts are aggregated at the economy-wide level in order to consider macroeconomic implications.

With respect to Ghana, the first article concentrates on specific issues of climate impact on water resources and agriculture demand. Specifically, Amisigo et al. [6] investigate the impact of climate change on crop yield, catchment runoffs, and water allocation across municipal/industrial, hydropower and agricultural uses. Four climate scenarios were considered. They represent the maximum variation in precipitation outcomes at the global and country levels ("global wet" and "global dry", and "local wet" and "local dry" scenarios), and span the full distribution of predicted changes in Ghana's climate moisture index. The authors found negative impacts of each of the climate scenarios on crop yields, with substantial variations across crops and regions. Surprisingly, their results indicated that even under the wet scenarios, the nation's water demand from municipal/industrial, hydropower and agricultural sources cannot be met simultaneously.

The second study, which was carried out by Twerefou et al. [7], employed the same climate scenarios and investigated the impact of climate change on road infrastructure in Ghana. The study found that adapting road networks to accommodate higher temperatures and potentially more intense rainfall can yield gains, particularly if these adaptation measures are incorporated into regular road rehabilitation and construction programs.

The third article employs results from the preceding two articles in order to assess the implications of climate change for Ghana's economy. For this study, Arndt et al. [8] employ a detailed computable general equilibrium model of Ghana. All the four ecological zones within the country were considered. The authors found, among other things, that climate change is expected to negatively impact national welfare or absorption. They proposed investment in agricultural research and extension and improved road infrastructure (sealing road surfaces) as cost-effective adaptation options.

The fourth paper on Ghana, which was written by Akpalu et al. [9], concerns optimum fisheries management under climate variability. The authors investigate the impact of changes in temperature and the variance of temperature on capture fish production in Ghana. Capture fisheries in Ghana are managed as open access, with some restrictions on fishing gears. This has led to overcapitalization and overexploitation. The authors hypothesize that, in addition to addressing the congestion externality in the fishery, polices aimed at sustainable management must account for climate impacts. Using data on fish catch, fishing effort, and temperature, the study found that both increasing temperature and variance of temperature negatively impact fish production.

As noted, this Special Issue has two articles on Ethiopia. The first considers land tenure security and climate impact on crop yield among female small landholders. The second considers climate variability and adaptation strategies of pastoralists. Both issues are critical yet have received very little attention in the literature. In most African countries, including Ethiopia, land tenure arrangements favor men [10]. In addition, compared to their male counterparts, female small landholder farmers face extra layers of constraints in input and output markets resulting in low and variable yields. Since male farmers face fewer constraints, a female small holder farmer could obtain a better return on her plot by renting it out to a male tenant. However, she then risks losing the plot to the male tenant. Akpalu and Bezabih [10] present a theoretical model and empirically investigate factors that influence the renting out decision. 
They found evidence that recent climate outcomes does influence the renting out decision, all else being equal. In addition, the results support the hypothesis that older female farmers or female farmers who have less fertile plots were more likely to rent out their plots.

The second article investigates adaptation strategies of traditional pastoralists in southern Ethiopia rangelands. The authors of [11] found that the pastoralists' perception of trends in climate change closely match actual climate data. The pastoralists adapt to climate stressors by shifting to non-pastoral livelihoods, moving around, and diversifying herd portfolio towards drought-tolerant species such as camels.

A study on fuel choice among households was carried out in Cameroon by Nlom and Karimov [12]. The situation in Cameroon mirrors the global estimate that over 70 percent of households in the developing world rely on biomass fuel leading to high levels of deforestation. Previous studies have found evidence of "energy transition" from traditional (biomass fuel such as firewood) to cleaner fuels (such as liquefied petroleum gas and electricity) as household income increases, all else being equal. The authors employed an ordered logic modeling technique to investigate factors that explain the choice among three cooking fuel sources: firewood, kerosene, and liquefied petroleum gas. Results indicate that the transition from traditional to clean fuels is at an early stage and only a substantial rise in income is likely to propel the shift.

Finally, four studies concerning Vietnam were assembled for this Special Issue. In each of these studies, climate forecasts from 22 general circulation models (GCMs) and three special report emissions scenarios (SRES) were employed providing 56 future climate scenarios (not 66 as not every GCM simulated every SRES). Based on these forecasts, Vietnam's surface temperature is expected to increase between $1{ }^{\circ} \mathrm{C}$ and $2{ }^{\circ} \mathrm{C}$ by 2050 due to climate change. But, impacts on precipitation are expected to be relatively mild with a slight tendency of drying out. The combination of slightly lower rainfall and higher evapotranspiration is expected to result in a mild "drying out" though both much wetter and much dryer outcomes are possible.

The first paper [13] focuses on the impact of climate change on irrigation, crops and hydropower in Vietnam. According to the authors, while some parts of the country are expected to experience drying trends others may experience substantial change in increased precipitation culminating in an increase in irrigation demand, higher frequency of negative impacts on agriculture, and a slight tendency for negative impact on hydropower. Furthermore, it was found that, compared to current conditions, dry and wet season runoffs are expected to change.

The second paper [14] focuses on road infrastructure. It looks at the potential impact of changes from climate stressors including: sea level rise, precipitation, temperature and flooding. Using traditional costing methods, the study found that it may cost the nation an additional US\$10.5 billion to maintain the current road infrastructure through 2050.

The third article [15] analyzes the impact of sea level rise and storm surge on the Red River delta region of Vietnam by combining sea level rise scenarios with simulated storm surge levels. The study found that between a tenth and four-fifths of the Hanoi region's GDP is at risk due to permanent inundation and periodic storm surges, respectively, due to sea level rise. Adaptation policies should include a planned retreat from the sea supplemented by construction of efficient seawalls on a selective basis.

As in Ghana, the fourth study employs results from the previous three studies in order to assess economy-wide impacts. Arndt et al. [16] use a dynamic computable general equilibrium model (CGE). 
Drawing from the previous three studies, the transmission channels considered were agriculture, energy, infrastructure, and the combination of sea level rise and cyclone strike resulting in more pronounced storm surges. They find that the overall climate impact is expected to be modest (a 1 to 2 percent reduction in GDP in about 2050) under most climate scenarios; however, the combination of high rates of sea level rise and a major cyclone strike in either the Red River or Mekong deltas raises the specter of very significant damage in these specific circumstances. The menace posed by the combination of sea level rise and a large cyclone strike is likely to grow in the latter half of the 21 st century posing difficult choices for policymakers.

In conclusion, the findings of the articles are diverse, pointing to the value of detailed country specific studies in the development of policies to confront the implications of climate change.

\section{References}

1. IPCC. Climate Change 2007: Impacts, Adaptation and Vulnerability; Contribution of Working Group II to the Fourth Assessment Report of the IPCC; IPCC: Geneva, Switzerland, 2007.

2. IPCC. Managing the Risks of Extreme Events and Disasters to Advance Climate Change Adaptation; Field, C.B., Barros, V., Stocker, T.F., Qin D.H., Dokken, D.J., Ebi, K.L., Mastrandrea, M.D., Mach, K.J., Plattner, G.K., Allen, S.K., et al., Eds.; Cambridge University Press: New York, NY, USA, 2012.

3. Meinshausen, M.; Meinshausen, N.; Hare, W.; Raper, S.C.B.; Frieler, K.; Knutti, R.; Frame, D.J.; Allen, M.R. Greenhouse-gas emission targets for limiting global warming to $2{ }^{\circ} \mathrm{C}$. Nature $\mathbf{2 0 0 9}$, $458,1158-1162$.

4. The African Development Bank (AfDB) Group. African Development Report 2012-Toward Green Growth in Africa. Available online: http:/www.afdb.org/fileadmin/uploads/afdb/Documents/ Publications/African\%20Development\%20Report\%202012\%20-\%20Overview.pdf (accessed on 21 August 2015).

5. IPCC. Climate Change 2001: The Scientific Basis; Houghton, J.T., Ding, J., Griggs, D.J., Noguer, M., van der Linden, P.J., Dai, X., Maskell, K., Johnson, C.A., Eds.; The Press Syndicate of the University of Cambridge: Cambridge, UK, 2001.

6. Amisigo, B.A.; McCluskey, A.; Swanson, R. Modeling Impact of Climate Change on Water Resources and Agriculture Demand in the Volta Basin and other Basin Systems in Ghana. Sustainability 2015, 7, 6957-6975.

7. Twerefou, D.K.; Adjei-Mantey, K.; Strzepek, N.L. The Economic Impact of Climate Change on Road Infrastructure in Sub-Saharan Africa Countries: Evidence from Ghana; WIDER Working Paper 2014/032; World Institute for Development Economics Research of the United Nations University: Helsinki, Finland, 2014.

8. Arndt, C.; Asante, F.; Thurlow, J. Implications of Climate Change for Ghana's Economy. Sustainability 2015, 7, 7214-7231.

9. Akpalu, W.; Dasmani, I.; Normanyo, A.K. Optimum Fisheries Management under Climate Variability: Evidence from Artisanal Marine Fishing in Ghana. Sustainability 2015, 7, 7942-7958.

10. Akpalu, W.; Bezabih, M. Tenure Insecurity, Climate Variability and Renting out Decisions among Female Small-Holder Farmers in Ethiopia. Sustainability 2015, 7, 7926-7941. 
11. Berhanu, W.; Beyene, F. Climate Variability and Household Adaptation Strategies in Southern Ethiopia. Sustainability 2015, 7, 6353-6375.

12. Nlom, J.H.; Karimov, A.A. Modeling Fuel Choice among Households in Northern Cameroon; WIDER Working Paper 2014/038; World Institute for Development Economics Research of the United Nations University: Helsinki, Finland, 2014.

13. Gebretsadik, Y.; Fant, C.; Strzepek, K. Impact of Climate Change on Irrigation, Crops and Hydropower in Vietnam; WIDER Working Paper, 2012/79; World Institute for Development Economics Research of the United Nations University: Helsinki, Finland, 2012.

14. Chinowsky, P.S.; Schweikert, A.E.; Strzepek, N.; Strzepek, K. Road Infrastructure and Climate Change in Vietnam. Sustainability 2015, 7, 5452-5470.

15. Neumann, J.E.; Emanuel, K.A.; Ravela, S.; Ludwig L.C.; Verly, C. Risks of Coastal Storm Surge and the Effect of Sea Level Rise in the Red River Delta, Vietnam. Sustainability 2015, 7, 6553-6572.

16. Arndt, C.; Tarp, F.; Thurlow, J. The Economic Costs of Climate Change: A Multi-Sector Impact Assessment for Vietnam. Sustainability 2015, 7, 4131-4145.

(C) 2015 by the authors; licensee MDPI, Basel, Switzerland. This article is an open access article distributed under the terms and conditions of the Creative Commons Attribution license (http://creativecommons.org/licenses/by/4.0/). 